\title{
The Judge Advocate General's Department in the American Expeditionary Forces
}

T

He Army has always occupied an important and prominent position in the life of this nation, from its very inception until the present day. The twentieth century dawned, finding the United States a world power, charged with all the duties and responsibilities of a national and international scope. As the nation had grown, so the Army had changed from the humble but truly valiant beginnings of Revolutionary days to an organization of a hundred thousand men and more. With this growth, came a realization that the efficiency of the Army would be increased and promoted by a departmentalization, and by putting specially trained men in that particular field where their training and natural adaptitude would accomplish the best results.

Immediately preceding our entry into the recent world war, the Army, in addition to the four combative branches of the service, ${ }^{1}$ had been divided in nine departments and corps, ${ }^{2}$ among which the Judge Advocate General's Department occupied a small ${ }^{3}$ but extremely important position. The Judge Advocate General's Department is charged with the administration of the courts-martial system and with the duties of legal adviser to all branches of the Army, with its manifold and innumerable questions involving all branches of law, both civil and military.

Military law is as clearly defined a system of laws as are the statute and common laws or the statute and civil laws prevailing in any state in the Union. It consists of the Articles of War, enacted by Congress, Regulations and Instructions, sanctioned by the President, the orders of commanding officers, and certain usages, customs, and precedents constituting the unwritten or common law of the Army. These, taken together, are the law

1 Infantry, Cavalry, Field Artillery and Coast Artillery.

2 General Staff Corps, Adjutant General's Department, Inspector General's Department, Judge Advocate General's Department, Quartermaster Corps, Medical Department, Corps of Engineers, Ordnance Department, and Signal Corps, authorized by U. S. Comp. Stats. § 1717a, 39 U. S. Stats. at L. 166, 9 Fed. Stat. Ann. (2d ed.) 926.

3 It was composed of 1 judge advocate general with the rank of brigadier general, 4 judge advocates with rank of colonel, 7 judge advocates with rank of lieutenant-colonel, 20 judge advocates with rank of major, together with acting judge advocates detailed from other branches of the service. 
military $^{4}$ of the land. To state that law, to guide by those precedents, to adapt both to the extraordinary conditions presented by a large army, operating on friendly but foreign soil, under pressing war necessities and under situations unexperienced and unimagined, were, along with the aid in the maintenance of military discipline, the outstanding duties of a Judge Advocate, serving in the theater of operations in the recent war with Germany.

\section{II}

Among the novel problems facing the American Expeditionary Forces (A. E. F.) in its infancy came the question of the relation of our military and civil law to the military and civil law of the territory in which we were operating. A clear conflict of authority existed and it was immediately necessary to determine and define the boundaries of French criminal and civil jurisdiction as it affected the A. E. F., its agencies, and the individual members thereof.

The jurisdictional question was brought to a head by two incidents. Soon after the first American troops landed upon French soil, a certain officers' mess was planned for organization in Paris and preliminary negotiations were discussed with $M$. Bcaucourt, chef, to serve as cook. However, this mess did not materialize, and M. Beaucourt felt duly aggrieved by the failure. $\mathrm{He}$ appealed to the Conseil de Prudhommes (a peculiarly French quasi-judicial institution for the adjustment of disputes between employers and employees). The crier of the court served a summons upon Major-General Kernan to appear before this court "At one-thirty in the afternoon .... to hear the claiming . . . . of the following sums, (a) 40 francs for salary; (b) 60 francs for breach of contract; (c) indemnity of 10 francs." The other incident was of infinitely grcater import. The steamer "Berwind," subsequently torpedoed and sunk, but then in the government transport service, collided with a vessel belonging to the Compagne Generale Transatlantique in the harbor of Bordeaux, causing

4 Military law is not to be confused with martial law, which is a term applied to the temporary government, by military authority, of a place or district in which, because of civil disorders, or a state of war and active military operations, the civil government is, for the time being, unable to exercise its functions. It is applicable to all persons and property within the district subject to it, is only temporary and ceases with the necessity which brought it into existence. It is not properly law, but substantially the "will" of the military commander. U. S. v. Diekelman (1875) 92 U. S. 520, 526, 23 L. Ed. 742. 
damage which resulted in a very large claim. The Compagne Generale proceeded at once to the local Tribunal du Commerce to have the vessel seized and held for release, subject only to a bond. In order to expedite the use of the vessel, a representative of the Army Transport Service did, in fact, execute a bond, without inquiring into the necessity or propriety of this act. Other vessels on similar occasions were seized by the local Tribunal du Commerce at $\mathrm{La}$ Rochelle, Brest, and Nantes.

With the question as to whether the A. E. F. in its "corporative" capacity as such was subject to the jurisdiction of the French authorities, little difficulty was experienced in view of the common acceptance of the doctrine of the international impropriety of the servants of one nation attempting to exercise force upon the agencies of another independent nation, and of the doctrine that one sovereign cannot have his sovereignty derogated by being summoned to appear before some judicial instrumentality of another sovereign. The French central authorities were disposed to concede the principle, but the difficulty was to have this principle accepted by the various localities and communities. This was finally accomplished by circular letters from the Ministre de la Justice, dated respectively February 20 and March 12, 1918, which were communicated to all the French courts and which announced the immunity from civil process of the A. E. F. and its proper legal agencies. England, Italy and Belgium likewise announced similar provisions within their territorial limits. However, to what extent the individual subject to military control might properly be included in this governmental immunity was not so easily adjusted.

The question first faced was that of criminal jurisdiction over individual members of the A. E. F. for offenses committed on French soil. From their experiences with other alien armies, operating within their territorial limits, and with a full appreciation of the existence of an American system of military law to punish offenders, the French were, from the first, disposed to admit the finality of our jurisdiction over our own soldiers. At first, by a "gentlemen's agreement" brought about by conferences between the Judge Advocate, Headquarters, A. E. F., the Judge Advocate, Lines of Communication (later changed to Service of Supplies so not to conflict with the designation Lines of Communication of the British) and $M$. Edouard Ignace, French Sous-Secretaire d'Etat de la Justice Militaire, the trial and punish- 
ment of our own soldiers was relegated to ourselves. In order to obviate any future misunderstandings, by an exchange of notes dated respectively January 3,1918, and January 14, 1918, between the Secretary of State of the United States and the French ambassador at Washington, an agreement ${ }^{5}$ embodying in general the terms of the former agreement was consummated, effective January 14,1918 , definitely recognizing our exclusive criminal jurisdiction over our soldiers.

Yet this agreement concealed an ambiguity. The definition of the word "persons" to include "any other person, who under the American ... . . law is subject to military ... . jurisdiction" was broad enough under our second Article of $\mathrm{War}^{6}$ to include civilian

5 "The Government of the United States of America and the Government of the French Republic agree to recognize during the war the exclusive jurisdiction of the tribunals of their respective land and sea forces with regard to persons subject to the jurisdiction of those forces, whatever be the territory in which they operate, or the nationality of the accused. In case of offenses committed jointly or in complicity with persons subject to the jurisdiction of the said military forces, the principals and accessories who are amenable to the American land and sea forces shall be handed over for trial to the American Military or Naval justice, and the principals and accessories who are amenable to the French land and sea forces shall be handed over for trial to the French Military or Naval justice. The government of the United States of America and the government of the French Republic further agree to recognize during the present war the exclusive jurisdiction within Amrican territory of American justice over persons not belonging to the French land and sea forces who may commit acts prejudicial to the said Military forces, and the exclusive jurisdiction within French territory of French justice over persons not belonging to American land and sea forces who may commit acts prejudicial to the said Military forces. The word 'persons,' as used in the first paragraph of this agreement, designates, together with the persons enrolled in the Army, Navy and Marine Corps, any other person who, under the American or French law, is subject to Military or Naval jurisdiction, especially members of the Red Cross, regularly accepted by the Government of the United States of America, or the Government of the French Republic, in so far as the American or French law and the customs of war place them under Military or Naval jurisdiction." This agreement was promulgated in Bulletin 13, G. H. Q., 18, Feb. 18, 1918, and published in Le Journal Official Feb. 16, 1918.

" "The following persons are subject to these articles and shall be understood as included in the term 'any person subject to military law,' or 'persons subject to military law, whenever used in these articles-

"(a) All officers and soldiers belonging to the Regular Army of the United States; all volunteers, from the dates of their muster or acceptance into the military service of the United States; and all persons lawfully called, drafted or ordered into, or to duty or for training in, the said service, from the dates they are required by the terms of the call, draft or order to obey the same;

"(c) Officers and soldiers of the Marine Corps when detached for service with the armies of the United States by order of the President:

"(d) All retainers to the camp and all persons accompanying or serving with the armies of the United States without the territorial jurisdiction of the United States, and in time of war all such retainers and persons accompanying or serving with the armies of the United States in the field, both 
employees accompanying the Army in the field. This, strictly construed, might be held to include French or other foreign civilian employees of the United States, and the agreement stated to contain a surrender, on the part of the French, of jurisdiction over French citizens and other foreigners who were civilian employees of the army for criminal acts committed on French soil. Such an assertion of jurisdiction was, of course, not within the intent of the original agreement and to clarify the situation a supplemental circular ${ }^{\tau}$ was issued by the Ministre de la Justice October 4, 1918, pointing out that the American authorities would not exercise jurisdiction over French nationals and other foreigners in their employ. Yet one enterprising judge advocate in Base Section No. 2 in the summer of 1919 entertained, for a short time, the idca of trying by court-martial some Spanish civilians, alleged to have committed larceny.

England likewise admitted the finality of our jurisdiction over our own soldiers and incorporated this in an amendment to the Defense of the Realm Act, ${ }^{8}$ effective March 22, 1918. Similar

within and without the territorial jurisdiction of the United States, though not otherwise subject to these articles."--2d Article of War, U. S. Comp. Stats. \& 2308a, 39 U. S. Stats. at L. 651, 4 Fed. Stats. Ann. (2d ed.) 1254.

i"The question has been raised whether civilian workmen, French, foreigners, or colonials, employed by the American A-my in the territory of the Metropolis are, as far as the Criminal Code is concerned, under the jurisdiction of French or American tribunals.

"In agreement with M. le Ministre des Affairs Etrangères, M. le Commissaire General aux Affairs de Guerre Franco-Americaines, and with the American Authorities, the competency of French tribunals must be exclusively acknowledged.

"Moreover, it is fully understood that magistrates shall give to American authorities the most effective help and that offenses which may come under their notice, shall be subject to as careful as possible an inquiry.

"Please bring the present instructions to the knowledge of your 'substitutes'."-Circulaire, Ministre de la Justice, dated October 4, 1918.

8 " 45 F. For facilitating the enforcement of His Majesty's Allies of discipline amongst such of their naval or Military Forces as may for the time being be within the United Kingdom, the following provisions shall have effect:

"(1) It is hereby declared that, subject to any general or special agreement, the Naval and Military Authorities and Courts of any Ally may exercise in relation to the members of any Naval or Military force of that Ally who may for the time being be in the United Kingdom all such powers as are conferred on them by the law of that Ally.

"(2) The Admiralty or Army Council may make orders authorizing the arrest and custody of members of any force of an Ally alleged to have been guilty of offenses, and, subject to any such agreement, as aforesaid, the handing over of such persons to the proper Naval or Military Authorities of the Ally whether within or outside the United Kingdom for the purpose of being dealt with (whether within or without the United Kingdom) by the Naval or Military Authorities or Courts of the Ally according to the law of the Ally."-Defense of the Realm Act, effective March 22, 1918. 
agreements were entered into with the Italian and Belgian authorities. Upon consummation of all these agreements, the military authorities had exclusive criminal jurisdiction over all soldiers, marines (detached for service with the Army by order of the President), field clerks, American civilian employees, Red Cross, Y. M. C. A., K. C., Salvation Army, and other "welfare" organizations personnel and all additional "retainers and persons accompanying or serving with the armies of the United States in the field."

Even this did not settle the problems of civil jurisdiction, to what extent the individual American soldier was responsible before a French court for individual debts, contracts, agreements, etc., especially as our military law afforded almost no redress for civil wrong or damages. The 105th Article of $\mathrm{War}^{9}$ offered a means of redress for injuries to property, but was faulty in that it did not cover anything except injuries and damages to property. Furthermore in case of a large claim, the remedy offered by the Article was more apparent than real, because as the individual's pay was comparatively small, an amount of money sufficient to cover this could not be stopped. On the matter of garnisheeing of pay or garnisheeing sums due upon contracts, the department followed the familiar rule of the United States that government moneys were not subject to such proceedings. The question as to the power of the French courts over the individual soldier for purely personal obligations was never squarely met, as there were obvious disadvantages to a definite decision either way. If immunity from civil process was granted, the reckless or thoughtless American soldier might be prone to make and break personal

9 "Whenever complaint is made to any commanding officer that damage has been done to the property of any person or that his property has been wrongfully taken by persons subject to military law, such complaint shall be investigated by a board consisting of any number of officers from one to three, which board shall .... assess the damages sustained against the responsible parties. The assessment of damages made by such board shall be subject to the approval of the commanding officer, and in the amount approved by him shall be stopped against the pay of the offenders. And the order of such commanding officer directing stoppages herein authorized shall be conclusive on any disbursing officer for the payment by him to the injured parties of the stoppages so ordered.

"Where the offenders cannot be ascertained, but the organization or detachment to which they belong is known, stoppages, to the amount of damages inflicted may be made and assessed in such proportion as may be deemed just upon the individual members thereof who are shown to have been present with such organization or detachment at the time the damages complained of were inflicted as determined by the approved findings of the board."-105th Article of War, U. S. Comp. Stats. $\$ 2308$ a, 39 U. S. Stats. at L. 667,9 Fed. Stats. Ann. (2d ed.) 1291 . 
obligations according to his whim; if the French authorities had exclusive civil jurisdiction, every town and village could hold a soldier till the culmination of a legal process, which would disorganize and disrupt our entire military organization. By an elaborate use of the 105th Article of War and by moral suasion, it was found possible to get most civil obligations satisfactorily adjusted without recourse to litigation.

Related to the same subject was the liability of the A. E. F. and its individual members to taxation. From the beginning, the department adopted the view familiar to American constitutional law that the power to tax included the power to destroy and that the propriety of the French government taxing our governmental agencies could not be favorably considered. The French government took a liberal view on this subject and exempted the A. E. F. and its members from the luxury tax, property tax, registration of contracts tax, etc.

There existed, however, a local toll known as the "octroi" over which the French government exercised no control, and which, indeed, it paid. This tax was a historic right of the towns and villages and was a tax upon consnmption-for example, upon all edibles or potables brought and consumed within the town limitsand was devoted to the maintenance of roads and streets. It seemed an absurdity to pay taxes upon American foodstuffs brought to France for the nourishment of the American Army, but some municipalities insisted upon their technical rights, although some freely waived this tax. After some negotiations with the French Military Mission, an agreement was reached whereby, pending a final settlement of the matter with each town, the French authorities were to refrain from collecting this tax, although an accurate record was to be kept to show the consumption of all articles subject to the tax. The entire matter was turned over to the Judge Advocate at General Headquarters (G. H. Q.), who, in co-operation with the Chief Quartermaster, sent an officer throughout France to make arrangements with the various municipalities either for exemption from the tax or for its adjustment on a per capita basis. It is interesting to note that the Assistant Comptroller of the Treasury had ruled that the tax was payable out of the appropriation for "tolls and ferriages."

\section{III}

Attached to each army, corps, division, and brigade, there were one or more officers from the Judge Advocate General's Depart- 
ment, or officers detailed as acting judge advocates. These officers were charged with duties in reference to their particular units, but did not take care of anything outside of these units. G. H. Q. could not directly handle the volume of work that came from other than combative units, and the Lines of Communication (L. O. C.), later Services of Supplies (S. O. S.), were established. Fron humble beginnings it grew until it embraced all except G. H. Q. and combative units, i. e., three-quarters of France, all of England, Belgium, and Italy, except that small portion actually occupied by combative units. The office of the Judge Advocate, S. O. S. (then L. O. C.) was inaugurated at Paris August 22, 1917, in charge of one officer with a clerical force of one. At this time, the command was still in embryo, decentralization of authority had not commenced, and the numbers of troops were very small. Indeed, plans for the future were not fully matured, nor the magnitude and variety of future judge advocate work fully realized. It then appeared that one Headquarters office for the S. O. S. would suffice to handle the coming situation, and that a personnel of fairly modest proportions would be required. Administratively the situation had not materially changed up to December 26, 1917, except that the volume of work had increased, causing an expansion of personnel to three officers and four clerks. However, with the advent of the new year, the A. E. F. grew with mushroom-like rapidity, and the department was daily confronted with the increasing pressure of work.

Efficient administration was handicapped by the dispersion of S. O. S. troops all over France, the tardiness of French mail and telegraph under war conditions, the great inadequacy of clerical aid, especially court reporters, and the fact that the Department, because of lack of personnel, had to depend for trial judge advocates on line officers who quite humanly regarded their line duties in war times as paramount, and court-martial duties as something to be avoided or at least completed with as little time and work as possible. Needless to say, the results of such a situation could hardly be desirable.

Out of this situation slowly evolved the policy of decentralization, and with it came increased efficiency. Decentralization commenced in the Headquarters' offices by departmentalization, in effect, into bureaus of Executive Administration, Military Law and Courts-Martial, Contracts and Finance, War Risk Insurance, Administrative Law, Transportation Matters, French and Inter- 
national Law, Civil Affairs, and Constitutional and Statute Law. With the approaching organization of the Base Sections, in effect dividing the territory wherein American troops operated into territorial departments, it became apparent that the desirable organization was a duplicate of the central office in each base to handle local legal problems and discipline. Base Section No. 3 (England), because of its remoteness, had been equipped with a judge advocate's office in December, 1917, and was thereafter operated under the general supervision of Headquarters S. O. S. Steps were taken to enlarge the personnel and to establish branch offices. Additional commissioned judge advocate personnel was recruited from the lawyers alrcady in France, from the ranks, from officers in other branches of the service, from welfare organizations, and by cable request to Washington.

G. H. Q. had been established at Chaumont, and Headquarters S. O. S. had been transferred from Paris to Tours. Thus G. H. Q., Hdqrs. S. O. S., and each Base Section, army corps, division, and brigade, was equipped with a Judge Advocate's office and the departmentalization and the decentralization did much to clarify the situation. The judge advocate of each combative unit was under the jurisdiction of its higher military unit, and finally under the jurisdiction of $G$. H. Q. All base sections were under the jurisdiction of Headquarters S. O. S. and that, in turn, was under the jurisdiction of G. H. Q.

\section{IV}

The court-martial, as a military tribunal, is not of modern origin. As a system of military justice and as an instrumentality to aid in the maintenance of discipline in armies, its history antedates the Christian era. It was developed by the Romans to the state of an exact science and from their system of jurisprudence it was borrowed by the Teutonic leaders during the Middle Ages, and adapted to the peculiar conditions of the feudal system. It was fully established in Continental Europe at the time of the Norman Conquest, and was introduced in the latter part of the 11 th century into England, as an incident of that system, by William the Conqueror, and his immediate successors. From this Court of Chivalry evolved the modern English courts-nıartial, with the American courts-martial patterned along similar lines. The constitutional authority and jurisdiction of a court-martial is found in Article I, section 8, of the Constitution, ${ }^{10}$ under which Congress

${ }^{10}$ Dynes v. Hoover (1859) 20 How. 65, 15 L. Ed. 838; Kirkman v. McClaughry (1907) 152 Fed. 255. 
may provide for the trial and punishment by courts-martial, without indictment or the intervention of a jury, of all offenses committed by persons in the military service of the United States, and this power is not abridged by the Fifth or any other amendment of the Constitution. ${ }^{12}$ Military law is enforced by courtsmartial. These tribunals are created by the order of a proper convening authority, and are empowered by statute, to try accusations against military persons, to reach findings of guilt or innocence respecting the same, and to impose appropriate sentences. These sentences are in the nature of recommendations only, and have no legal validity until they have received the approval of the military commander, called the reviewing authority. Courts-martial are not a part of the judiciary system proper, but an attribute of command. The findings of a court-martial cannot be set aside nor reviewed by courts of the United States, or of any state. ${ }^{13}$ However, the Federal courts, but not the local or state courts, can examine to see that the military courts keep within the boundaries of their jurisdiction, but can go no further. ${ }^{14}$ Courtsmartial are classified, in accordance with their jurisdiction, into general and inferior courts-martial, the latter term including the special court-martial, and the summary court. There composition and jurisdiction are so well known as to make any discussion of that subject unnecessary.

Under the provisions of the 8th Article of War, the commanding officer of any army, army corps, division, or separate brigade has the power to appoint a general court-martial, and G. H. Q. was early given general court-martial jurisdiction. On September 4, 1917, by War Department cable, the Commanding General, S. O. S., was advised that the President had granted him general court-martial jurisdiction under the authority of the 8th Article of War. From that date until April 7, 1918, general court-martial jurisdiction for the entire S. O. S. (except England, granted jurisdiction November 14, 1917) was centralized at S. O. $\mathrm{S}$. Headquarters and the records of all trials inspected and reviewed there. The policy of decentralization has already been

11 Johnson v. Sayre (1895) 158 U. S. 109, 39 L. Ed. 914, 15 Sup. Ct. Rep. 773.

12 Ex parte Milligan (1866) 4 Wall, 2, 18 L. Ed. 281.

13 Keyes v. U. S. (1883) 109 U. S. 336, 27 L. Ed. 954, Sup. Ct. Rep. 202; Ex parte Reed (1879) 100 U. S. 13, 25 L. Ed. 538; U. S. v. Maney (1894) 61 Fed. 140.

14 Ex parte Bright (1874) 1 Utah, 145. 
mentioned, and to follow out this policy properly, decentralized general court-martial jurisdiction was necessary. Upon the recommendation of the Judge Advocate S. O. S., such jurisdiction was promptly granted to the Base Sections.

Cases flowed in from all points of the compass and increased in number with the increase of troops. Today some curious major who had opened a port-hole of the "Leviathan" while a submarine encounter was in progress would be asked to explain before a court-martial this disregard for the lives of his fellow soldiers, while tomorrow it might be some sergeant who had felt such a proprietary interest in government supplies that he was selling sugar and cigarettes to an enterprising French merchant. The situation at Headquarters S. O. S. will serve as a barometer of the entire A. E. F.

Soon after general court-martial jurisdiction was exercised in the A. E. F., it became patent that most line officers had little appreciation of the utility of company discipline under the 104th Article of $W a r,{ }^{15}$ or of the difference between the functions of summary, special, and general courts-martial. There was a strong tendency on their part to pass the determination of all matters of this nature to Headquarters by preferring charges and recommending trial by general court-martial. Special laxity was displayed in the matter of technical form and proper preparation of charges.

In an endeavor to ameliorate this situation, the Judge Advocate drafted a proposed general order, and recommended its issuance. This was approved, and it was issued as General Order No. 8, Headquarters, L. O. C., October 27, 1917, directing all officers' attention to the diminution of the number of general courts-martial by the use of the 104th Article of War, the special court-martial, and the summary court, and to the proper preparation of all charges and specifications. In passing it is well to note that during the entire existence of the Department in the A. E. F., it was the

15 "The commanding officer of any detachment, company, or higher command may, for minor offenses not denied by the accused, impose disciplinary punishments upon persons of his command without the intervention of a court-martial, unless the accused demands trial by court-martial.

"The disciplinary punishments authorized by this article may include admonition, reprimand, withhholding of privileges, extra fatigue, and restriction to certain specified limits, but shall not include forfeiture of pay or confinement under guard. ... The commanding officer who imposes the punishment, his successor in command, and superior authority shall have power to mitigate or remit any unexecuted portion of the punishment. . "104 th Article of War, U. S. Comp. Stats. $\$ 2308$ a, 39 U. S. Stats. at L. 667 , 9 Fed. Stat. Ann. (2d ed.) 926. 
uniform policy to keep the number of trials by general court to a minimum.

This General Order was helpful in correcting the situation, but a new difficulty speedily arose. It was found that, in such cases as were in fact referred to a general court, the members of the court and the trial judge advocates were often inexperienced in the discharge of their duties and that the records of trial were poorly prepared, particularly with respect to the technical requirements of the record. In an attempt to reduce this undesirable situation, a sample general court-martial proceedings was prepared for distribution to the president of each court and to each new trial judge advocate. This latter was supplemented by a memorandum setting forth the customary errors found in court-martial procedure and records. The utility of these measures was at once manifest. The department was continually handicapped by untrained trial judge advocates, and inadequate clerical aid, especially court reporters.

As an evidence of the number of cases, from the opening of S. O. S. Headquarters until July 11, 1919, there were 30,000 inferior courts-martial and some 508 cases by general court, in that jurisdiction alone. There is nothing in the nature of the cases, inferior or general, to elicit special comment, except perhaps that the number of serious offenses considered crimes in civil law was extremely low in proportion to the number of soldiers in the command. But two cases of murder arose in Headquarters S. O. S.; and only some eleven cases of capital punishment in the entire A. E. F. were reported, the death penalty being given only for murder or rape. The majority of offenses were purely military, absence without leave, disorderly conduct, and so on. The prevalent offense of commissioned personnel was drunkenness or disorder growing out of that condition. The General Order that all men contracting venereal disease should be court-martialed brought its volume of work, and all reports of the Chief Surgeon were carefully checked against the results of the trial. One general offense was the larceny of government property. Wholesale thievery was discovered at Le Havre, Marseilles and Chenonceaux, in consequence of which some sixty officers and enlisted men were brought to trial and punished. Another set of cases worthy of mention were the so-called "Prison Farm" cases, in which four officers and six sergeants were tried on charges of consistently abusing and maltreating soldiers appre- 
hended as "A. W. O. L." in Paris and gathered for safe keeping at Prison Farm No. 2, pending return to their organizations. Of the men sent to the prison camps at General Intermediate Storage Depot, who received a sentence of three years or more, with the exception of desertion, cowardice in the face of the enemy, and one case of disobedience of the orders of a commissiond officer, all were found guilty of some offense which was a crime at civil law, notwithstanding statements of any congressman to the contrary.

In many cases the accused and the witnesses were in different parts of the A. E. F., and early the policy was adopted of concentrating them wherever it could be done, with the least time and expense to the government. The department was constantly confronted with the difficulty and, in some cases, the impossibility of securing witnesses. Troops were moved with great rapidity, and the Central Records Office and the Troop Movements Officer were often tardy in furnishing the necessary information as to whereabouts of a particular organization. This difficulty was doubled after the Armistice, when troops were being rapidly moved back to the States. Very often by the time the department received the information, it would be found that the witnesses and sometimes the accused were on the Atlantic, if not, in fact, in the United States and discharged. In some few cases, usually involving moral turpitude, both witnesses and accused were returned to the A: E. F. from the States, and in others the witnesses or the accused sent to the States for the trial. There came a time when military justice, important as it was, had, of necessity, to give way to the repatriation of the troops. In August, 1919, in all cases except those involving moral turpitude and those of a serious nature, the offenders were sent to the base ports and to the States for discharge.

As part of the administration of discipline by courts-martial comes the question of the handling of soldiers who have been convicted by a court-martial and who are in the status of garrison or general prisoners. Owing to the rapidity of troop movements and to the nature of their duties, it was not an easy matter to oversee or guard prisoners, or to find useful occupations for them. It was decided that the most efficient course was to establish central prison camps, where convicted soldiers could be gathered, properly supervised and properly worked. It happened at this time that the Chief Engineer was undertaking large construction 
work at Gievres, which necessitated hard labor on the part of many, and for that reason Gievres was selected as one central prison camp. For a like reason, St. Sulpice was selected as the other. Commanding officers were directed to send all prisoners there who had sentences exceeding three months, but this was later modified to cover only those who had more than six months' confinement to serve. Particular care was given to the investigation of prisoners at these camps with the view to clemency for good conduct, and, as a general policy, dishonorable discharge was suspended, unless the offense committed involved moral turpitude, so that the prisoner might be given a chance to redeem himself and resume the honorable status of a soldier. A judge advocate, trained in disciplinary matters, examined into the clemency and good-conduct credit in vogue at these prisons and made recommendations relative to this matter.

This war has taught us many serious lessons, and only as we profit by our past mistakes do we progress. Too much emphasis cannot be placed upon the fact that the A. E. F. was "over court-martialed." Commanding officers were given broad discretionary powers, but instead of using them wisely, were prone to prefer charges against a soldier for the slightest infraction. The department had adopted a policy of reducing court-martial trials to a minimum. As an evidence of this, at Headquarters S. O. S. in 1917-1918, 364 charges were received recommending trial by general court-martial, yet after a careful consideration of each case and the evidence therein, only 243 were referred for trial. Common sense and company discipline will do much to remedy this condition and promote the efficiency and welfare of the Army.

\section{$\mathrm{V}$}

Under the American system of government, in war, as in peace, no public official, and no public agency, civil or military, can expend one penny of the public funds, or bind the American people to any enterprise, except by virtue of some definite grant of power from the Constitution, or from the statute law. Hence, despite the presence of an Assistant Comptroller of the Treasury in Paris, no small part of the work of the Judge Advocate was concerned in advising the Commander-in-Chief and various staff departments as to what expenditures were appropriate, how they might be made, what permanent improvements could be laid down on French soil, and how settlement for them could be reached, what contracts were duly authorized, how they should be drawn, or 
how, having served their usefulness, they might be terminated. The thoroughness with which the department was obliged to go into the complex questions of finance from a legal and practical side, is perhaps best illustrated by saying that when the time came to select a chief finance officer for the A. E. F., a member of the Judge Advocate General's Department was so designated.

Millions of francs' worth of supplies were purchased in France and England for the Army, and each department, as the Quartermaster, Ordnance, etc., at first, drew up the contracts for their individual needs. From the legal standpoint, these contracts represented a remarkable chaos and resulted in some very serious claims being presented. Very often, in fact, in the majority of contracts, there was no cancellation clause, and with the Armistice and the necessity of many kinds of supplies ceasing, an attempt was made to cancel these contracts. The total amount of claims presented because of this lack of foresight would be staggering; suffice it to say that one claim alone, and it was by no means the largest, was for 1,153,000 francs. This costly lesson should not be forgotten. The Judge Advocate General's Department was finally charged with this important work of preparing and passing on contracts and the conditions were greatly improved.

VI

Each judge advocate was constantly confronted with questions of War Risk Insurance and compulsory allotments, and at G. H. Q. and S. O. S. separate departments were inaugurated to deal with the very technical questions involved therein. As the operation of the War Risk Insurance Act in the A. E. F. was identical with that in the United States, it will not be further discussed here.

\section{VII}

Transportation by sea of hundreds of thousands of troops and hundreds of thousands of tons of supplies gave rise to numerous legal complications connected with the interpretation of contracts and agreements, and the adjustment of claims for loss or damage. The immunity of the A. E. F. and its agencies has been previously considered, but in admiralty matters the situation was somewhat different. In several instances, the Tribunal du Commerce asserted jurisdiction over an American transport, but clearly it was without jurisdiction. The Tribunal du Commerce has jurisdiction only in cases involving "commerce." A vessel operated by a government and engaged in transporting materials of war for it, is not engaged 
in "commerce." Therefore, wholly apart from the fact that the court was without jurisdiction because the claim was against a friendly sovereign government, it would be without jurisdiction, because our transports were not engaged in commerce. ${ }^{18}$

However, local authorities were inclined at times to assert jurisdiction and this resulted in addressing a letter on March 11, 1918, to the French authorities, requesting that the French courts be informed of their lack of jurisdiction. The Ministre de la Justice promptly issued a circular to the French courts reminding them that

"the Courts cannot render judgment in cases instituted against foreign Governments and their Agents on account of transactions carried on by the latter in the performance of their functions."

This lack of jurisdiction might give rise to an inequitable situation, as the following instance will indicate. The S. S. "Isabella" was requisitioned February 4, 1918, through the Shipping Board, authorized thereto by the President's Executive Order of July 11, 1917, pursuant to the Act of Congress approved June 15, 1917. She was operating under the "Time Form" of Requisition Charter (U. S. Shipping Board Charter, Form No. 2), under the terms of which the owners were liable for the results of any collision. On March 15, 1918, while going up the Charente River, she collided with the British S. S. "Morriston," the owners of which claimed that the "Isabella" was at fault. If the United States plcaded inmunity from the jurisdiction of the French courts on the ground that the master and crew, guilty of negligence, causing the injury, were the agents of the United States, the claimants would come to the courts in the United States for satisfaction. In such a case it would be embarrassing to decline responsibility on the ground that, under the contract between the owners and the United States, the owner assumed liability for collisions. By depriving the claimant of his usual remedy against an owner, namely, his right to proceed in rem, we would force him to go to the United States in order to bring suit in a jurisdiction where the owner could be personally served with process. Furthermore, the owner would not be held liable when it was shown that the persons navigating the ship at the time of the

${ }^{10}$ Circulaire de Ministre de la Marine, 22 Mai, 1865; Fuzier-Herman v. Abordage N. 206; Conseil de Prefecture du Nord 5 Décembre, 1894-Clunet 1895 , p. 570 , cons. d'Etat 15 Février 1872-Lenon, p. 90. 
collision were "the immediate employees and agents of the United States" unless it were held that they remained at the time, and in relation to the navigation of the ship, agents of the owner, or unless it were held that the charter gave a right of action in favor of third persons, against the owner of the ship, both of these propositions being subject to contingencies. On the other hand, there was no provision in the contract by which the United States could, if it settled the claim, recover back from the owner the amount paid out. As a practical solution of this inequitable situation, in case of vessels operating under the "Time Form" charter, every effort was made to induce the owner (or insurers) to bond the ship or otherwise to assume their liabilities. Most requisitioned ships were operated under the "Bare Boat" Charter, which provided that the United States should assume all risks. Therefore, as to such vessels, none of the above complications existed and if any claims arose, the United States alone was interested, and the Court of Claims, and, later the Rents, Requisitions and Claims Service, offered a simple remedy.

The matter of admiralty law fully occupied the time of experienced admiralty lawyers at Headquarters S. O. S. and London. In order to have the necessary information to assert or refute a claim, extensive forms were prepared, to be filled out in case of any collision. As an indication of the size of the claims, in one case alone, the damage, including demurrage, claimed by the other ship was $\$ 300,000$, while the damage to our ship was estimated at over $\$ 75,000$.

By special arrangement in Washington with the Attorney General, the Judge Advocate S. O. S. was authorized to adjust claims of the United States for damages and to accept payment therefor. The occasion for granting this special and unusual authority arose when an English concern voluntarily offered a sum in payment of damages to a vessel which it acknowledged without dispute. The Claims Department of the Rents, Requisitions, and Claims Service was finally entrusted with the payment of all claims, still leaving all the other manifold questions of admiralty law to be decided by the department.

\section{VIII}

Just as the movements of troops and supplies by water gave rise to questions in admiralty law, the movement of the same troops and supplies by land gave rise to many legal questions. To understand properly the stupendous scale on which the A. E. F. 
was operating, it must be remembered that there were locomotives and cars, built by Americans in the United States or in France, operated by American crews and propelled by American fuel, on some 8000 miles of French track, in addition to the miles upon miles of American-built track; huge roundhouses and repair shops, where American soldiers performed the arduous task of keeping the trains and engines in good repair; Is-sur-Tille with its 280 kilometers of sidetracks, and Gievres, Romorantin, and St. Sulpice with nearly as many; an American "special" operating between Tour and Chaumont; a separate department for the operation of trains under the supervision of one of the heads of the Pennsylvania Railroad. The difficulty was increased by the fact that American trains on French tracks must be routed in conjunction with French and English trains on the same tracks, all operating under pressing war necessities.

To handle the many technical matters, members of the Department who had been upon the legal staff of railroads in the United States were detailed and attached to the office of the Director General of Transportation, and to increase their efficiency they were also made representatives of the Claims Department of the Rents, Requisitions, and Claims Service, which position enabled them to voucher for payment matters, which they had, in their legal capacity, determined to pay.

Aside from the questions of agreements and contracts and the proper mode of cancelling them when the Armistice came, a great many claims were presented by the eight principal railways of France. These claims embraced a diversity of subjects, though generally originated from damages done to trains and equipment while soldiers were riding on them, theft of property, usually foodstuffs and wines, and damages to stations, turntables, etc. The American doughboy developed many peculiar habits while in France, and a very favorite form of amusement was to appropriate lamps for use in billets, or to use the signal apparatus as a pistol target. Tapping barrels of "vin blanc" and "vin rouge" by bullet holes, followed immediately by rushes of canteens and tin cups, kept the prohibition wolf away from the door up to the time of departure for the States. Railroad gates seemed to have been an especial object of prey for the American truck driver. The truck driver continued to cross tracks, without stopping, in hopes that some time the gate might not be there, and there was hardly a gate in the American area that did not have one claim tacked on 
to it, and not infrequently two or three. A remaining considerable class of claims grew out of the misdelivery of cars which often resulted in the appropriation of their contents to uses for which they were not intended. Trains were turned over to the Americans at Is-sur-Tille, Gievres, Montoire, Bassens-Bordeaux, and other places where the A. E. F. was conducting huge projects and sometimes contained cars assigned to French individuals, and sent in error to the American yard. These cars would be appropriated by the Quartermaster, Ordnance or other department or corps expecting a shipment of like material, and a claim was the inevitable result. In one case, a shipment of a car of rabbit-skins was received, and after due consideration, a brilliant quartermaster accepted it on the theory that it was salvage from the Germans. It was promptly sold for 20,000 francs; and as it was worth 100,000 francs, some Frenchman felt duly aggrieved. Claims arising from this source amounted to approximately $3,000,000$ francs.

\section{IX}

It is impracticable, if not indeed undesirable, to endeavor to touch in any detail upon the myriad of points, great and.small, concerning French and international law. Suffice it to recite several of the interesting problems. Many civilian employees were in American employ, and as their contracts were to be interpreted by the French law, this, together with the interpretation of contracts for supplies, was the birthplace of many mooted questions. If a civilian employee of the Army is discharged without notice, in an absence of a provision in the contract relative thereto, what were his rights? An interpreter was discharged by the Ordnance Department in Tours in 1919, and claimed, in addition to other damages, 3000 francs for "mental anguish." Could and should this be allowed?

In connection with the desertion of American soldiers, the question arose as to whether the French gendarmes could be paid the customary reward. It was decided, since the French gendarmerie is militarized and operates under the Ministre de la Guerre, that they were not civilians and hence not payable under our statutes, as were other French police. France and the allied nations paid a reward of twenty-five francs to the gendarme for each capture and it was recommended by the Department that steps be taken to secure authorization to do the same.

Could prisoners of war be transferred to the United States? 
The treaty between Prussia and the United States concerning the treatment of prisoners, ratifications of which were exchanged June 22,1800 , made it appear that they might be transferred. A number of special points came up, such as the possibility of a prisoner accepting a promotion which he had received before being captured, but knowledge of which came to him subsequent thereto, the hours of labor, the propriety of working non-commissioned officers, and the responsibility of the government for the loss of prisoners' baggage. Likewise the question arose whether or not we could turn over all prisoners of war to the French, and return our Prisoners of War Escort Companies to the States, but the Treaty of Versailles effectively disposed of that point.

One vexatious problem never did get itself properly and clearly settled - that of compensation to civilian employees for occupational injuries while in American employ. Whether or not the domestic Federal statutes with respect to compensation could be said to operate on French soil, was a mooted question until the United States Employees Compensation Commission formally decided that it could. The French government unofficially leaned to the view that even if it could, it ought not to as a matter of policy because the differences in the American and French rates of payment were such as could not but cause comment, unfavorable to the lower French rates. Claims relating to these injuries were finally turned over to the representative of the United States Employees Compensation Commission, who opened his headquarters in Paris. It should be noted that up to August, 1919, no definite basis of settlement had been decided upon.

$\mathrm{X}$

Here it would seem appropriate to discuss the Rents, Requisition and Claims Service. This service, though totally distinct from the Judge Advocate General's Department, originated, however, under the oversight of the Judge Advocate, S. O. S., who has been identical with the director of that service throughout its existence. In addition thereto, it was always interrelated with the Department, and members of the Judge Advocate General's Department were detailed as heads of its various departments and guided its destiny.

The Rents, Requisitions and Claims Service (known as R. R. and $C$. to the initiated and as "Rest, Recreation, and Comfort" to the uninitiated) was one of the most remarkable products of the war. This service was unknown before the war, and the express 
purpose of its establishment was to preserve the good name of the United States; to prevent military operations from being hampered by ill will or lack of confidence on the part of the French people; to do justice to the inhabitants; to avoid a large number of exaggerated claims after the war; and to adjust small claims so as not to interfere with the performance of military duty. The authority for the payment of claims was granted by an Act of Congress, April 8, 1918, which provided for payment of claims of inhabitants of France or any other European country not an enemy nor an ally of any enemy, for damages, caused by American military forces, which were payable according to the law or practice governing the military forces of the country in which they occurred. The functions of the service can best be described by a reference to its name.

It was charged with the leasing of land and buildings necessary to the successful operation of the army; it billeted hundreds of thousands of soldiers in barns, cottages, chateaux, casernes, and castles and paid 50,000,000 francs for these; rented 15,000 pieces of property for offices, hospitals, and projects-installations as they were called; rented 73 hotels in Vichy, and hotels and rooms at Biarritz, Nice, and other watering places, for the convalescent and soldiers on leave and paid 700,000 francs for damages after the soldiers had left; provided quarters for supplies, and animals as well. Let it be emphatically stated that at no time were rentals paid for front-line trenches, as such, as has been often supposed and reported in the press. It did pay for land necessary for training purposes and upon which trenches incidentally were dug for instructive purposes. Likewise in one instance it did pay for land used for instruction purposes, which after one bad push of the Germans was occupied by front-line trenches; but of course this had previously been leased for training purposes.

It had officers attached to the British Claims Commissioner, the French Ministry of War, and the Director General of Transportation; officers in the different section into which France, England. Belgium, Luxembourg. Italy, and Germany had been divided; established 2,220 town and zone majors to acquire property, and supervise its rentals, investigate and handle claims arising out of the presence of American troops; and had 600 officers and 400 clerks at Headquarters. It maintained a school where officers were given instruction relating to the nature of the work-French law, forms, bulletins, and circulars. It handled claims for both 
the Army and the Navy; paid for personal injuries and property damages caused by American trains, trucks, automobiles. It was called on for anything from a request made on General Pershing to have some officer's wine bill paid, to a request to procure the approval of the General Staff and then rent a barn for 10 francs for boxing scheduled that night at St. Fierre des Corps. No claim of any enemy national was ever paid.

Under the French law, and we, of course, followed this in France, the government is not liable for "faute personnelle" or "fait de guerre," but is liable for "faute de service." Translated liberally, these mean personal faults, risks of war, and faults of service. An illustration of a "faute personnelle" is larceny or burglary committed by a soldier. An automobile under Army orders carried dim lights, before the cessation of hostilities, and ran into a railroad gate, the lights on which were dark blue and very indistinct under war regulations. After the Armistice, American soldiers gathered together a number of "duds," put them into a pit, and exploded them. The gas corroded the telephone wires, and rails. Both of the above claims were disallowed as "fait de guerre." Claims for injuries to buildings, because of the billeting of American troops there, would be allowed as "faute de service." In artillery practice at Camp Souge near Bordeaux, during dry weather and a high wind, the woods were set on fire. A claim of 2,000,000 francs was adjusted, as this was not a "fait de guerre," but a pure case of negligence.

Under the French law, the people constantly appeal to the head of the nation, and hardly a day went by without receiving a communication to President Wilson. ${ }^{18}$ Although the $R$. R. and C.

18 This letter will indicate the general tenor:

"From: Mlle. H. Martel, Institutrice, Baraques Chardin, Fontaine-les-Luxenil, Haute Savoie.

"To: President Wilson:

"Sir:

"We have in France a familiar proverb which reads as follows: 'It is much better to apply to God than to his Saints.' I am going to experiment if, having applied for no purpose to all the American Authorities, I will obtain justice from the Man who said he came to us to inaugurate in the whole world, the reign of the Right.

"I suppose you are aware of the stronger and stronger reprobation which, since 5 months, is coming out of the French conscience, as concerns the way you have dealt with our country's promordial interests. However the first responsible are the men in charge of the future of France, who did not defend her, even against you, and have so badly interpreted the will of the $1,700,000$ dead who have mealt their fiesh and their blood with the sacred ground they were fighting for. You are not a Frenchman and cannot feel 
money claims for death and personal injuries, it did not have jurisdiction to pay the two claims certified as follows:

"I, the undersigned, Lescreait Hippolyte, certify to have received from $M$ me. Collet, the sum of 12 francs for tolling the bells for the funeral services of $\mathrm{M}$. Collet.

\section{"Lescreait Hippoly"e."}

"Eugene Fouquet certifies to have received from Mme. Jardeau the sum of 50 francs for champagne for her husband. "Eugene Foduet, Gravedigger."

Under the French law, the tenant has to pay for reasonable as well as unreasonable wear and tear. To determine this, it is necessary to prepare and sign an "etat des lieux," or condition of the premises when the tenancy begins. This is frequently an elaborate document of hundreds of pages, itemizing every scratch, nail, spot, and doorkey. The French key, besides being an important addition to the world's supply of metal, has acquired an almost sacred character, and many a bearded "bailleur" has shed manly tears over the loss of this symbol of home, now doubtless gracing the walls of an ex-soldier's room in Squirrel Glen and labeled "Key to Hindenburg's Headquarters." In contradistinc tion to the usually lengthy "etat," one was received as follows: "Open meadows, no roads, no trees, no walls, nothing."

Open claims were usually substantiated by a "process verbal," which was a report of the gendarme that he, on duty at the Resident de la Justice, "clothed in my uniform and conforming to the orders of my superior and acting in accordance with an order from the Magistrate" interrogated everyone, drew a diagram of the

and think as a Frenchman does, so, with good faith, you have been mistaken, in your looking for Right.

"But my private case is far more simple and I will sec if you will keep your word.

"On September 30, 1918, two American soldiers came to me askiug for food, in reality to look over whether they could find anything to steal. When they had eaten well, they thanked me by robbing me of my gold watch, present value 300 francs. These soldiers were arrested scveral days later by the gendarmeric of St. Loup-sur-Semouse (Hte. Sayoic) and the Camp Commandant at Bains stated to the gendarmerie that $I$ would be indemnified. Since then $I$ have been waiting, and $I$ have not yet received any answer to my claims addressed to Camp of Bains, Epinal A. P. M., P. M. Paris, General Pershing, and even to Mlle. Margaret Wilson.

"Now, Monsieur le President, to you, the Man of Right, I am claiming what is my right. France and the French have suffered enough in the last five years, they have been made poor enough, they have been ruined enough, and the Americans need not contribute to the universal pillage. Once more, $\mathrm{I}$ am waiting.

"Please accept, Monsieur lc President, my respectful regards, 
occurrence and found the facts. These claims were signed by the mayor of the commune, the clerks, or by the liaison officers in the French Mission, and transmitted to the R. R. and $C$. to be acted upon.

The soldiers in the A. E. F. were the cause of many curious claims (e. g., a hotel keeper in Pau put in a claim for three crush opera hats and a doll's baby carriage), and the R. R. and C. was the recipient of most of them, but an occasional one was headed off. The 29th Military Police Company earned the thanks of the $R$. R. and C. when the claim of Mme. Sophie Guillame was disclosed:

"Claim received on Form 51 on January 15, 1919. Statement of Sophie Guillame-I had a beautiful cat which I loved very much, she was very beautiful. I need her. She caught rats and mice. Besides that she was my companion. I loved her very much, because she was very beautiful.

"An American soldier said in that house of Theveny that they had eaten a cat on Christmas day. I have not seen her for fifteen days. She never strayed out more than a week before. I therefore ask for an indemnity, francs 20.00 , for my cat, she was a beautiful beast.

$$
\begin{aligned}
& \text { "Sophie Guildame, Place du Marche." } \\
& \text { 1st Ind. }
\end{aligned}
$$

From: C. O. 29th Military Police Company.

To: Commanding General 29th Division.

Subject: Alleged eating of cat.

1. On January 7th, 1919, Mme. Guillame reported that American soldiers had kjlled and eaten her cat for their Christmas dinner.

2. Upon investigation, the following facts were ascertained:

(a) Cat was missing on January 7, 1919.

(b) Statement of Mme. Guillame attached.

(c) Statement of Mme. Theveny and her mother that Mme. Guillame was queer and that they advised paying no attention to her.

(d) Gendarmes officially reported this morning ( January $14,1919)$ that the cat came back.

3. In view of the above, this case has been closed.

(Signed) Captain Military Police Co.

$\mathrm{XI}$

And so the volume and variety of questions which the Department was called upon to solve were both interesting and great. When a French freighter operated by an American crew collided in an Italian harbor with a British transport loaned to the Belgians and directed by a Belgian master, under what law are the damages 
to be settled? How near a base hospital is it appropriate, under the laws of war, to place an artillery park? If an enlisted prisoner of war, after capture by our forces, receives notice that he has been promoted a second lieutenant, shall we treat him as an officer or as an enlisted man? How can a sergeant at Coblenz stay there, yet marry a girl in Des Moines, Iowa? Has the Commanding General S. O. S. authority to raise pigs? May two brothers each draw commutation for the same mother? When a major, Reserve Corps, and a captain, Regular Army, are each promoted to colonels, National Army, on the same day, who ranks whom? May an ordnance officer patent an invention he has hit upon during government time, and through the use of government material? Is an olographic will valid in Vermont? Does a field clerk occupy the status of an officer, an enlisted man or neither? Can Army military police arrest a sailor? If an officer uses government material in the construction of a special automobile body for his official use, what action shall be taken? Is this income return correct? How drunk does a colonel have to be before he is guilty of "conduct unbecoming an officer and a gentleman"? Was this confession properly admitted by a court-martial? What basis shall be used for determining the damage to burned buildings, pre-war prices, cost of reproduction, or expected prices in the future? Shall Y. M. C. A. personnel be allowed to entertain German prisoners? Shall official notice be taken of the fact that an American officer gained entrance to the Casino at Monte Carlo in civilian clothes and tempted the Goddess of Fortune? Can this soldier be allowed to visit his relatives in Switzerland? Shall mileage be paid to an officer when the journey is made by aeroplane? If a soldier is guilty of bigamy, has he sinned against military law? If a soldier hit an Irishman in Dublin, shall he be sent there for trial after he has returned to his organization at Marseilles? Shall the United States pay for damages to French roads? How shall a contract for the purchase of $10,000,000$ francs of supplies from the French be drawn? If the Quartermaster's Department, through an error, bills coffins to the Red Cross as bath tubs, who shall pay the freight? Does an ordnance colonel to qualify for promotion have to pass an examination in equitation? Can this contract be cancelled without liability? And so on through permutations impossible to reckon.

In public and constitutional law, there are and have been since the United States came into being, two opposite views of 
legal interpretation-the strict constructionist view which plays upon the letter of the law, and makes law a bloodless end in itself, feeling content if the "science" is maintained even though the public interest perish, and the broad constructionist view which first looks to legitimacy and desirability of the administrative end, and then to accomplish a legitimate, desirable, but new end, draws fresh deductions from the spirit of old statutes on the theory that they are animate, and progressively adaptable to changed conditions of public need. This latter view consistently governed the Department, whose manifold decisions have attempted to contribute in some small way to the efficient, constructive, practical and quick dispatch of the Army's business without the injection of technicalities or pettifogging objections. A rule was early adopted that no paper or communication, whatever its nature, should leave the Department without a concrete, unevasive, helpful solution as to the future and proper disposition of the question in hand, regarded from an administrative as well as from a legal standpoint, keeping in mind that the Department was but one cog in a powerful military machine with but one idea-a military victory.

Gerald H. Hagar.

San Francisco, California. 